J. Pcrinat. Med.

2 (1974) 185

\section{Creatinine levels in first urines of male preterm and term infants}

\author{
Axel Fenner, Gerd-Ulrich Lange, Dieter Mönkemeier and \\ Gerhard Ohlenroth
}

\author{
Division of Neonatology, Pediatric Center and \\ Division of Obstetrics and Gynecology, Surgical Center I \\ Medical School, Lübeck, Germany
}

Received: January 13, 1974. Accepted April 16, 1974.
In the course of a study on urinary estriol levels in preterm and term infants, creatinine determinations were performed as reference values to calculate estriol-creatinine ratios [3]. Since information on creatinine levels in newborns is not available over a wide range of birth weight and gestational age, we considered it worthwhile to give a separate report of these data.

Creatinine reaches the urine almost exclusively, by glomerular filtration [1]. Thus endogenous creatinine clearance has been used as a means of assessing glomerular filtration capacity both in health and disease [1]. In utero metabolism is at a more steady state than postnatally: There is a steady influx of nourishment via the umbilical vessels, physical activity is limited and it may be assumed that protein catabolism also is more constant and even than after birth [4].

If these assumptions are in fact correct, a single urinary creatinine level reflecting such steady inutero conditions, would be sufficient to yield information about the state of glomerular filtration capacity. The first urine passed after birth, would meet these criteria. McCANCE reported that glomerular filtration rate is markedly reduced in preterm infants [6]. This should be reflected in the creatinine levels with which this paper is concerned.

\section{Materials and methods}

A total of 227 first urine samples were obtained by placing a sampling bag over the external genitals of male preterm and term newborns immediately at birth. Sixty six observations were excluded from the present study on the following grounds: Respiratory distress syndrome (RDS) in 13, intrauterine growth disturbance in 16,

\section{Curriculum vitae}

Axel Fenner, born 1935. Medical education at the Universities of Kiel, Vienna, Heidelberg and Freiburg. Postgraduate training at the University of the Saarland and in USA. Worcester (Mass.): Rotating internship. Children's Hospital, Univ. of Cincinnati (Obio): Residency in pediatrics. Children's Medical and Surgical Centre, Jobns Hopkins Univ., Baltimore (Md.): Research fellowship in neonatal biolog)' and pediatric pulmonary' phy'siolog)'.

1967 assistant at the Institute of Pbysiolog)', Rubr-University, Bocbum.

Since 1968, Children's Hospital of the Medical School Lübeck. Habilitation 1969, promotion to "apl. Professor", 1972. July 1973 to June 1974 on sabbatical leave from Lübeck at Department of Pediatrics, Univ. of Rhodesia, Salisbury', R/sodesia. Since August 1974 Head, Division of Neonatolog)'.

Research interests: Onset of breatbing at birth, periodic breathing in premature infants, neonatal biolog)', thermoregulation in premature infants.

postmaturity syndrome in 10 , infants of diabetic mothers 4 infants, ceasarean section in 16, birthweight of more than $4500 \mathrm{~g}$ without apparent reason in 6 , twin pregnancy in 4 , incomplete record of prenatal and postnatal course in one infant. It is assumed that the remaining 161 infants included in the series, are representative of a "healthy preterm and term newborn population". Among these, birthweight ranged from 1260 to $4320 \mathrm{~g}$, gestational age from 28 to 42 weeks. The exclusive use of male infants was for reasons of convenience: In females, urine samples often get lost or are inaccurate with respect to volume and timing. 
To determine urinary creatinine, the method of KINGSLEY and SCHAFFERT [5] was slightly modified to adjust for the small volumes of urine usually obtained: The frozen urine sample was thawn and diluted to $1 / 30$ of its concentration by the addition of distilled water. For protein precipitation, $2 \mathrm{ml}$ sodium wolframate in sulfuric acid were added to $0.6 \mathrm{ml}$ of the diluted aliquot, plus $1 \mathrm{ml}$ of distilled water. After shaking the sample was allowed to sediment for $5 \mathrm{~min}$., then it was centrifuged at 3000-4000 $\mathrm{rpm}$. Of the supernatant, $2 \mathrm{ml}$ were separated to which $1 \mathrm{ml}$ of freshly prepared alkaline picrate solution was added. Exactly $15 \mathrm{~min}$ later the photometer extinction reading was taken at a wavelength of $564 \mathrm{~nm}$, comparisons being made to standard and zero. Results were expressed as $\mathrm{mg}$ creatinine $/ \mathrm{ml}$ urine.

The data are presented according to birthweight and gestational age. Median values and total range are given for each group. A chi square test was performed to demonstrate the significant difference of urinary creatinine in term as compared with preterm infants.

\section{Results}

Graphic representation of the results obtained in our study (Figs. 1 and 2) shows that urinary creatinine levels are low in both, the low birthweights group $(<2500 \mathrm{~g})$ and the low



Fig. 1. Amount of creatinine in first neonatal urines Grouping of infants by birth weight.

Dots represent median values for each group, upper and lower limits indicate total range of values. gestational age group' ( $<37$ weeks). The ranges are extensive.

When all values are grouped into two categories according to the classic definition of "prematurity" versus "maturity", i. e. below and above $2500 \mathrm{~g}$ birth weight and/or gestational age of less or more than 37 weeks, chi square analysis (Tab. I and II) reveals statistically significant differences between each of the two groups: $0.5 \mathrm{mg}$ of creatinine per $\mathrm{ml}$ of urine is the dividing line between "premature" and "mature" newborns.

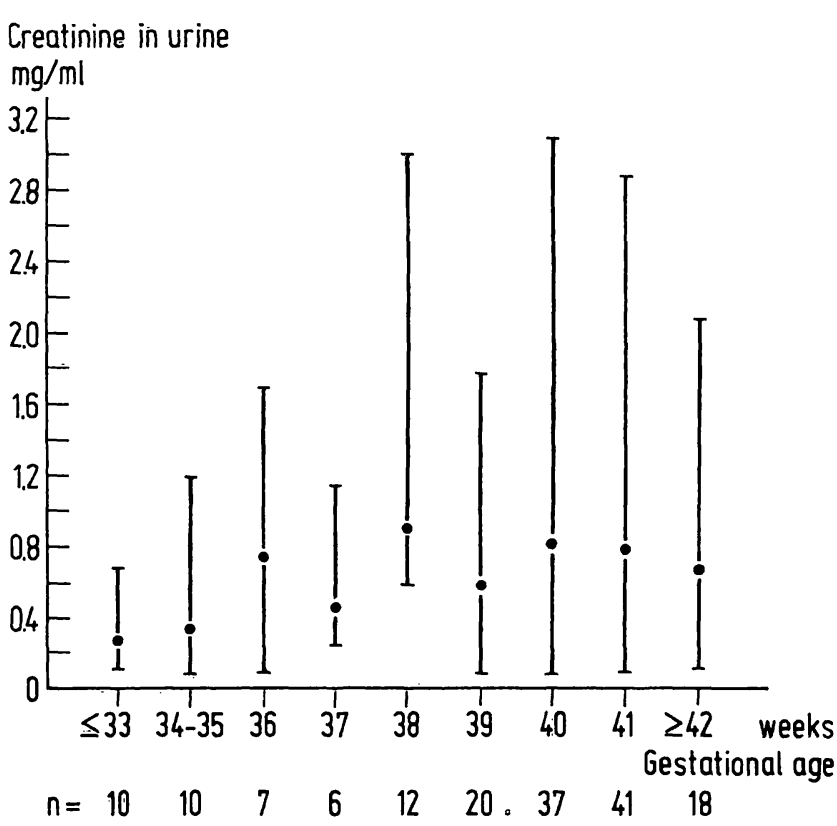

Fig. 2. Same arrangement of urinary creatinine levels as in Fig. 1, grouping by gestational age.

Tab. I. Chi square analysis of differences in creatinine levels of first neonatal urines comparing low birth weight infants $(<2.5 \mathrm{~kg}$ ) with normal weight newborns $(\geqq 2.5 \mathrm{~kg}$ ). At a dividing creatinine level of $0.5 \mathrm{mg} / \mathrm{ml}$ of urine the difference between the two groups is statistically significant at the $1 \%$ level $(p<0.01)$.

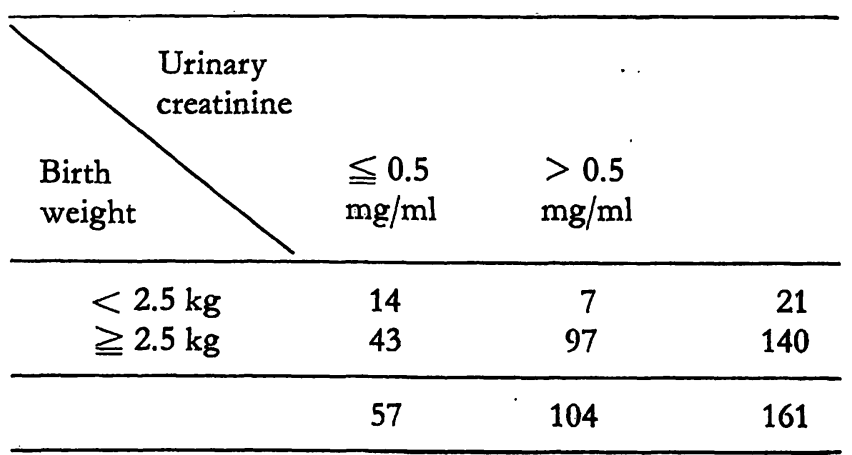


Tab. II. Similar analysis by chi square method as in Tab. I with 37 weeks serving as the dividing line between preterm and term infants. The difference is statistically significant at the $5 \%$ level $(\mathrm{p}<0.05)$

\begin{tabular}{|c|c|c|c|}
\hline Gestational Urina & $\begin{array}{r}\leqq 0.5 \\
\mathrm{mg} / \mathrm{ml}\end{array}$ & $\begin{array}{c}>0.5 \\
\mathrm{mg} / \mathrm{ml}\end{array}$ & \\
\hline$<37$ weeks & 17 & 14 & 31 \\
\hline \multirow[t]{2}{*}{$\geqq 37$ weeks } & 41 & 89 & 130 \\
\hline & 58 & 103 & 161 \\
\hline
\end{tabular}

\section{Discussion}

The results clearly indicate that creatinine excretion at birth is significantly lower in preterm than in term infants.

\section{ummary}

Creatinine reaches the urine almost exclusively by glomerular filtration. It is assumed that there is an even flux of protein forming material via the umbilical vein during in-utero existence. Hence creatinine excretion in utero should also be more continuous than postnatally, when protein intake becomes less even in accordance with food intake. In addition, physical activity in utero is limited thus rendering large alterations in creatinine excretion unlikely. If these principles of even in-utero creatinine excretion are accepted, the amount of creatinine present in the first neonatal urine may be considered a parameter signifying maturity of the glomerular filtration capacity. To test this hypothesis, creatinine levels were determined in the first urines of male newborns of variable maturity as judged by gestational age.

Creatinine determinations were done in the first urines of 161 healthy male preterm and term infants (birthweight $1260-4320 \mathrm{~g}$, gestational age $28-43$ weeks) using a
Though there may be considerable sample-tosample variation in the urinary creatinine levels of any given individual [2], we believe that having done all determinations on first postnatal urine specimens, creatinine excretion can be assumed to be fairly constant (see introduction).

Thus the differences in concentration between different individuals in the present series must be regarded as a reflection of renal glomerular functional capacity. Thus the results are in full agreement with MCCANCE's statement about the reduced glomerular filtration rate in preterm as compared to term infants [6]. Furthermore, the stepwise fashion in which creatinine levels rise, suggests a sudden rather than a gradual maturational step in glomerular function at about the same time at which many other organ systems mature.

Clearly the wide scatter in individual results precludes this test as a means of assessing neonatal maturity, in general.

modification of the method of KINGSLEY and SCHAFFERT [5]. The results (Figs. 1-2) indicate a direct relationship between creatinine excretion and degree of maturity. The increase is not continuous but rather, it shows a stepwise elevation of creatinine levels at a weight 2500 to $3000 \mathrm{~g}$ and/or at a gestational age of more than 35 weeks. This phenomenon is particularly noticeable in Tab. I and II where the dividing line for creatinine concentration has arbitrarily been set at 0.5 with the "mature" vs. the "premature" infants ( $\$ 37$ weeks vs. $\$ 2500 \mathrm{~g}$ ) having been grouped accordingly. The differences between each of the two groups are statistically significant.

We believe that these results may be considered a reflection of the functional maturation of glomerular filtration capacity. Certainly the scatter is too wide to permit the use of this test in the diagnosis of maturity in the individual case.

Keywords: Creatinine (urinary), creatinine excretion in newborns, creatinine and glomerular filtration in newborns.

\section{Zusammenfassung}

Kreatininspiegel im ersten Urin männlicher Früh- und Reifgeborener

Kreatinin gelangt fast ausschließlich über die glomeruläre Filtration in den Harn. Da anzunehmen ist, daß in utero der Fluß von Eiweißaufbaustoffen über die Nabelvene relativ gleichförmig ist, müßte auch die Kreatininausscheidung kontinuierlicher sein, als es im postnatalen
Leben bei wechselnder Nahrungsaufnahme zu erwarten ist. Hinzu kommt, daß die körperliche Aktivität in utero eingeschränkt ist, so daß auch von daher große Schwankungen der Kreatininexkretion nicht auftreten können. Akzeptiert man diese Prämissen, so kann dic Kreatininmenge im ersten Neugeborenenharn als Reifeparameter für den funktionellen Zustand der glomerulären 
Filtrationskapazität angesehen werden, wenn man die Untersuchung an Neugeborenen unterschiedlichen Maturitätsgrades durchgeführt.

Nach einer Modifikation der Methode von KINGSLEy and SCHAFFERT [5] wurden Kreatininbestimmungen im ersten Harn von 161 gesunden, männlichen Früh- und Reifgeborenen (Geburtsgewicht 1260-4320 g, Schwangerschaftsalter 28-43 Wochen) durchgeführt.

Die Ergebnisse (Figs. 1 und 2, Tabs. I und II) zeigen, daß die Kreatininausscheidung im ersten Harn bei schwereren bzw. reiferen Neugeborenen größer ist als bei leichteren bzw. unreiferen. Dies ist besonders ausge- prägt in der Darstellung na̛oh Geburtsgewichtsgruppen (Fig. 1), wo ein sprunghafter Anstieg der Zentralwerte bei Neugeborenen über $2500 \mathrm{~g} \mathrm{zu}$ verzeichnen ist. Ein Vier-Felder-Test (Tab. I und II) ergibt in beiden Kategorien (Geburtsgewicht und Schwangerschaftsalter) statistisch signifikante Unterschiede zwischen "reifen" und "unreifen" Neugeborenen.

Wir sind der Ansicht, daß diese Ergebnisse als Spiegel der funktionellen Reifung der glomerulären Filtrationskapazität anzusehen sind. Die breite Streuung der Werte erlaubt jedoch keineswegs, diesen Test zur Reifediagnose im Einzelfall einzusetzen.

Schlüsselwörter: Harn-Kreatinin, Kreatinin, Kreatinin bei Neugeborenen, Kreatinin und glomeruläre Filtrationsrate.

\section{Résumé}

Le taux de créatinine dans les premières urines de nouveaux-nés de sexe masculin prématurés et nés à terme

La créatinine parvient dans l'urine presqu'exclusivement par l'infiltration glomérulaire. Comme il est à supposer que, dans l'utérus, l'écoulement des matières anaboliques de protéine par la veine ombilicale est relativement constant, l'élimination de créatinine devrait être plus continue que dans la vie postnatale où l'alimentation est variée. De plus, l'activité corporelle étant réduite dans l'utérus, l'excrétion de créatinine ne peut subir de grosses fluctuations. Partant de ces hypothèses, on peut prendre la quantité de créatinine des urines du nouveau-né comme paramètre de maturité pour l'état fonctionnel de la capacité de filtration glomérulaire pour l'examen de nouveaux-nés dont le degré de maturité diffère.

Employant une méthode modifiée de KINGSLEY et SCHAFFERT [5], on a procédé à des déterminations de créatinine dans les premières urines de 161 nouveaux-nés de sexe

masculin prématurés et nés à terme (poids à la naissance 1260 - $4320 \mathrm{~g}$, âge de grossesse 28 - 42 semaines).

Les résultats (Fig. 1 et 2, Tab. I et II) montrent que la clearance de créatinine dans les premières urines est plus grand chez les nouveaux-nés plus lourds ou "mature" que chez les nouveaux-nés plus légers ou moins "mature". On s'en aperçoit plus particulièrement en observant les groupes des nouveaux-nés répartis selon leur poids (Fig. 1) où apparaît une hausse brusque des valeurs centrales chez ceux dépassant $2500 \mathrm{~g}$. Un Test de Quatre-Champs (Tab.I et II) donne dans les deux catégories (poids de naissance et âge de grossesse) des différences statistiquement significatives entre les nouveauxnés «mature» et ceux «immature».

Ces résultats nous paraissent refléter la maturation fonctionnelle de la capacité de filtration glomérulaire. L'étalement des valeurs, toutefois, ne permet en aucun cas de recourir à ce test pour le diagnostic de maturité dans les cas particuliers.

Mots-clés: créatinine (urinaire), créatinine chez les nouveaux-nés, créatinine et taux de filtration glomérulaire.

\section{Acknowledgments}

We are indebted to Mrs. Volkwartz and Mrs. Schalk for technical assistance and to Dr. W. Castre (Univ. of Rhodesia) for help with the statistical analysis of the data.

\section{Bibliography}

[1] Bennet, W. A., G. A. Porter: Endogenous creatinine clearance as a clinical measure of glomerular filtrations rate. Brit. med. J. 4 (1971) 84

[2] Edwards, O. M., R. I. S. Bayliss, S. Mrllen: Urinary creatinine excretion as an index of the completeness of 24-hour urine collections. Lancet 2 (1969) 1165

[3] Fenner, A., G. U. Lange, D. Mönkemeier, G. OHLENROTH: Estriol excretion in the first-voided urine of male newborns. Relationship with birth weight and gestational age in healthy infants and in those affected by the respiratory distress syndrome. Biol. Neonate 1974 , in press

[4] Fomon, S. J.: Body composition of the male reference infant during the first year of life. Pediatrics 40 (1967) 863

[5] Kingsley, G. R., R. R. Schaffert: Creatinine. In: MacDonald, R. P.: Standard methods of clinical chemistry. Academic Press, New York 1953

[6] MCCANCE, R. A.: Renal physiology in infancy. Amer. J. Medicine 9 (1950) 229

Prof. Dr. Axel Fenner

Division of Neonatology, Pediatric Center Medical School D-2400 Lübeck/Germany 